\title{
Cell-type-specific expression of epidermal cytokeratin genes during gastrulation of Xenopus laevis
}

\author{
Milan Jamrich, Thomas D. Sargent, and Igor B. Dawid \\ Laboratory of Molecular Genetics, NICHD, National Institutes of Health, Bethesda, Maryland 20892 USA
}

\begin{abstract}
Analysis of the spatial pattern of expression of embryo-specific epidermal cytokeratin genes in Xenopus laevis shows earliest activity in the animal pole cells of stage-9 blastulae. These genes are transcribed predominantly in the epithelial or outer ectoderm, to a lesser extent in the sensorial or inner ectoderm, and at low levels if at all in other regions of the embryo. In the early gastrula the entire ectoderm, including preneural and preepidermal regions, expresses cytokeratin mRNAs; accumulation of these mRNAs in preneural cells is terminated after contact is made with involuting chordamesoderm. On the basis of this and earlier work (Sargent et al. 1986) we suggest that the pattern of expression of cytokeratin genes in frog embryogenesis is based on prelocalized components modulated by the inductive influence of involuting chordamesoderm. The cytokeratin proteins are deposited in the form of filamentous networks in both layers of the epidermis. In the epithelial layer, a much denser mesh of filaments is facing the outside of the embryo. This polarity is established at the onset of the polymerization of these filaments. Thus, intraembryonic and intracellular localization of keratin gene expression and protein deposition is established at the onset of activation of these genes.
\end{abstract}

[Key Words: Keratin; cytokeratin; gastrulation; Xenopus laevis; ectoderm; neural induction]

Received December 29, 1986; revised version received and accepted February 3, 1987.

From the transcriptional point of view, amphibian development can be divided into three distinct periods. The first period is devoted to the transcription of maternal RNA and takes place during the many months of oogenesis (Anderson et al. 1982; Smith and Richter 1985; for review, also see Davidson 1986). Fertilization starts the second period, which is characterized by an absence of measurable RNA synthesis. After $7 \mathrm{hr}$, transcriptional activity is initiated at what is called the midblastula transition (Bachvarova and Davidson 1966; Newport and Kirschner 1982). The onset of transcription results in the apparent reactivation of some of the genes already transcribed during oogenesis as well as in the activation of a set of genes that had not been expressed before (Sargent and Dawid 1983). Shortly after the onset of zygotic transcription, the different cell lineages start to differentiate into morphologically distinguishable tissues. Whereas maternal RNAs are transcribed within one cell, i.e., the oocyte, a switch from uniform to cell-type-specific gene expression must take place to allow development of the multicellular embryo. This cell-type-specific expression could start as early as the midblastula transition, when the zygotic genome is activated, or could coincide with or follow the appearance of morphologically distinct tissues.

In general terms, the appearance of cell-type-specific gene expression can be the result of two distinct though nonexclusive phenomena: prelocalization of determinants of maternal origin, or induction through cellcell contacts established during development. Both processes are known to play an important role in amphibian development (see Gerhart 1980; Dawid and Sargent 1986). Two fundamental cell types (ectoderm and endoderm) which give rise to all other cell types, are already specified at the eight-cell stage and their establishment does not require inductive interactions (Nakamura et al. 1971). Mesoderm specification begins in early cleavage and requires inductive interactions between cells of ectoderm and endoderm (Holtfreter and Hamburger 1955; Nieuwkoop 1969, 1973; Nakamura et al. 1970; Gurdon et al. 1985; Jamrich et al. 1985). Differentiation of all other cell types depends on elaboration of and interactions between these three cell types. Ectoderm differentiates into epidermis or neural tissue, depending on whether it comes in contact with chordamesoderm (Vogt 1929; Holtfreter and Hamburger 1955; Keller 1975, 1976). To evaluate the relative role of prelocalization of determinants versus induction, there has been an effort to find tissue- and stage-specific biochemical markers (Ballantine et al. 1979; Bravo and Knowland 1979; Slack 1984, 1985). It has been shown that certain antigens are expressed only in epidermal cells by stage $121 / 2$ (Jones 1985; Jones and Woodland 1985; Akers et al. 1986). However, these markers are first activated after gastru- 
lation is well underway, and therefore do not provide information about the role of prelocalization versus induction in their initial expression.

In this work, we have used cytokeratin genes as markers for ectodermal differentiation during blastula, gastrula, and neurula stages of Xenopus laevis. Our laboratory has isolated and characterized a set of embryoand tadpole-specific cytokeratin genes from Xenopus and has shown that these genes are activated in the late blastula stage (Jonas et al. 1985; Winkles et al. 1985; E. Jonas et al., unpubl.). In this paper, we use in situ hybridization and immunocytochemistry to detect keratins and their mRNAs in the embryo. Keratin gene expression is the earliest cell-type-specific marker available in amphibian development, allowing the study of the mechanism of tissue specification during early ectoderm differentiation.

\section{Results}

\section{Expression of cytokeratin RNA in Xenopus tadpoles}

Three cDNA clones expressed specifically in embryonic and tadpole stages have been identified by sequencing as encoding epidermal cytokeratins. The structures of these three clones, DG70, DG76, and DG81, have been described previously (Jonas et al. 1985; Winkles et al. 1985; E. Jonas et al., unpubl.). The three genes have an identical spatial expression pattern during development and therefore they were used interchangeably. Figure 1

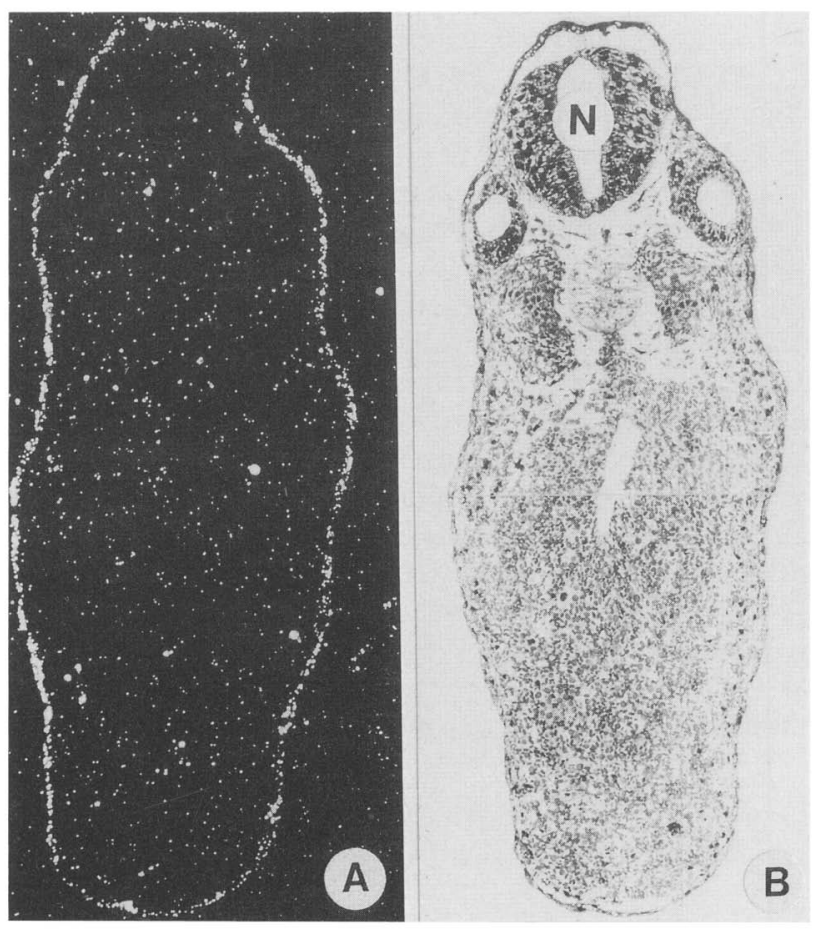

Figure 1. In situ hybridization of DG81 to sections of stage-40 tadpole. Hybridization is almost exclusively to the epidermis. The ectoderm-derived neural tube $(\mathrm{N})$ does not show any hybridization. $(A)$ Dark-field illumination; $(B)$ bright-field illumination. shows in situ hybridization of cRNA prepared from clone DG81 to a methacrylate-embedded section of a stage-40 tadpole. This and all subsequent in situ hybridization experiments used albino embryos to avoid confusion of silver grains with pigment granules. Silver grains are located almost exclusively in the ectodermderived epidermis, whereas the ectoderm-derived neural tube is negative. Having established the final pattern of expression of these genes, we proceeded to analyze their expression from the time of activation.

\section{Transcription of cytokeratin RNA in Xenopus blastulae}

The earliest time at which we detected cytokeratin mRNA was stage 9 (late blastula). The absence of detectable signal at earlier stages indicates that the hybridization seen in older embryos is not due to cytokeratin mRNA of maternal origin. There is at least one keratin mRNA in the egg (Franz and Franke 1986), but its sequence is quite different from DG70, DG76, and DG81, and there is no cross-hybridization. Figure $2 \mathrm{~A}$ shows a Northern blot analysis of RNA isolated from the animal and vegetal third of 7- to 9-hr-old (stages 9-10) embryos. Hybridization is found in the animal-third RNA; this region gives rise to the ectoderm. Figure $2 \mathrm{~B}$ shows a Northern blot analysis of RNA isolated from epithelial and sensorial ectoderm of stage-10 embryos; hybridization is predominantly to the epithelial (outer) layer of the ectoderm. This is also clearly visible in Figure 3 which shows in situ hybridization of DG76 probe to a section of stage-10 1/2 ectoderm: The signal is almost exclusively in the epithelial region. At this or any other stage studied there is little or no detectable hybridization to endoderm (not shown).

\section{Expression of cytokeratin mRNA in preneural ectoderm}

At the end of blastula development, the ectoderm is radially symmetric; its differentiation into epidermal and neural pathways is initiated during gastrulation. It is generally thought that neural differentiation is induced in otherwise undetermined ectoderm by the involuting chordamesoderm (see Jacobson and Rutishauser 1986). Although the position of the future neural plate is predictable once a dorsal lip forms at the beginning of gastrulation (and from cytoplasmic movements earlier; see Sharf and Gerhart 1983; Vincent et al. 1986), there is no known physical attribute associated with preneural ectodermal cells in the early gastrula. Cytokeratin gene expression was studied during gastrulation to ask at which stage the neural and epidermal lineages diverge with respect to activity of these genes. The sections shown in Figure 4 cut an early gastrula (stage $10 \cdot 1 / 2$ ) along its dorsal/ventral midline, i.e., through the center of the dorsal lip. This section is one of a set of serial sections, assuring correct orientation. In situ hybridization shows that the animal pole region, much of which will develop into epidermis, contains keratin mRNA (Fig. 4B). The critical region is shown in Figure 4E: This ectodermal subregion will become neural plate in a few 


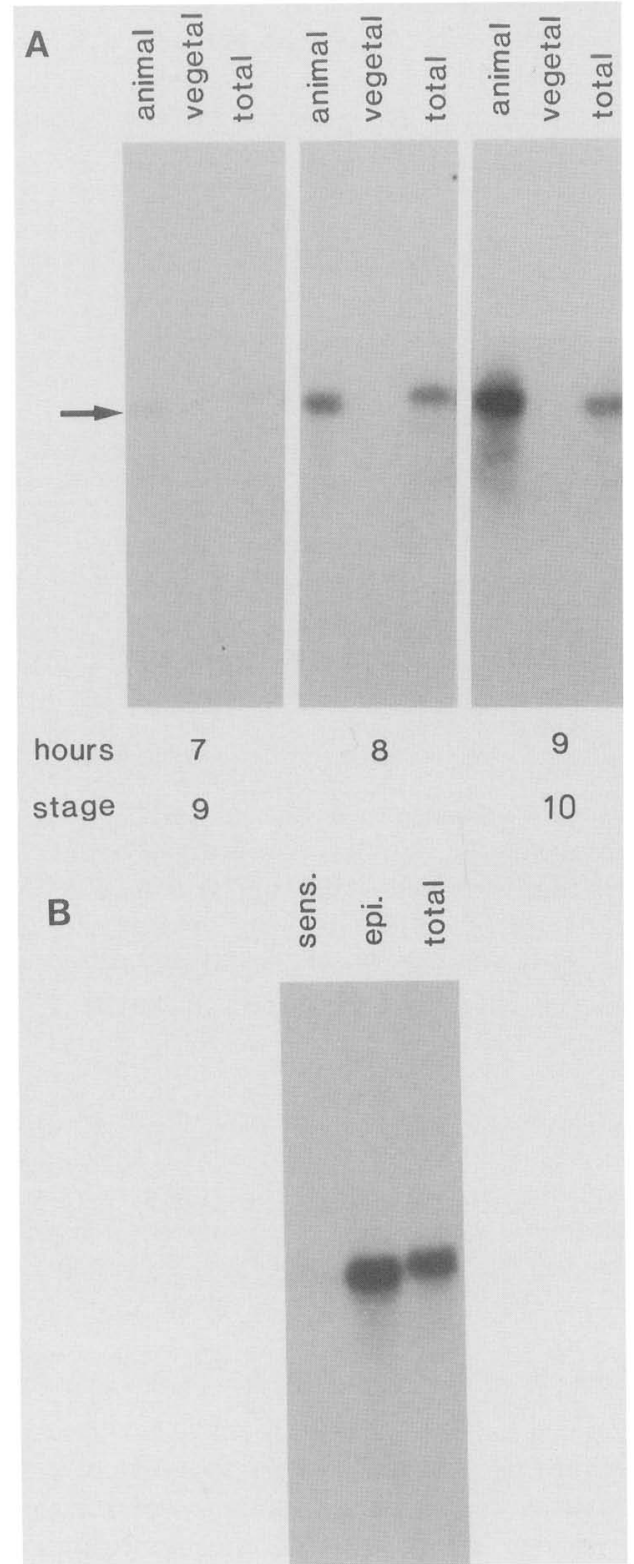

Figure 2. Localization of cytokeratin mRNA in dissected regions of Xenopus embryos. (A) Northern blot analysis of RNA form the animal and vegetal third of 7-, 8-, and 9-hr-old embryos using nick-translated DG70 DNA as a probe. The cytokeratin RNA is present in the animal pole cells from $7 \mathrm{hr}$ (stage 9) on. (B) Northern blot analysis of the RNA extracted from epithelial and sensorial ectoderm of stage- 10 embryos using the same probe as in $A$. The DG70 gene is predominantly expressed in the epithelial ectoderm.

hours' development. Yet, keratin mRNA is present in much of this region (upper or animal pole-proximal half of the segment in Fig. 4E). Transcription of keratin genes has terminated in the progressively enlarging neuroectoderm (lower or vegetal pole-proximal half of the Fig. 4E segment). At any stage of gastrulation, ectoderm in contact with the leading edge of chordamesoderm still contains epidermal cytokeratin mRNA, as it does in Figure $4 \mathrm{E}$. If the preneural ectoderm were already determined
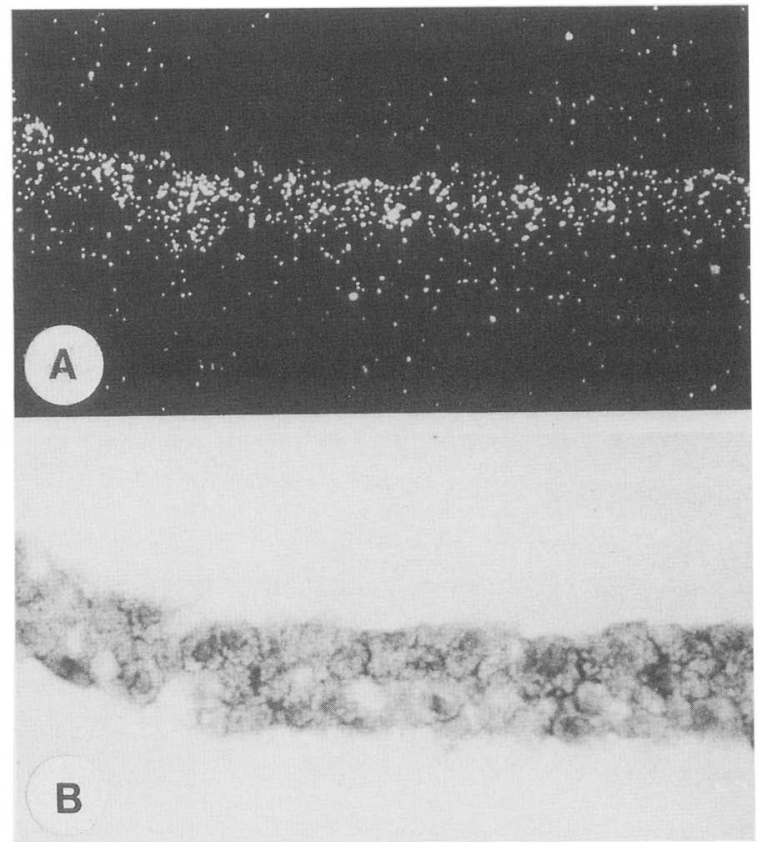

Figure 3. In situ hybridization of DG76 to a section of the blastocoel roof of stage-10 1/2 embryo. The hybridization is to the epithelial layer of ectoderm. Outside of embryo at top and blastocoel cavity at bottom of figure. $(A)$ Dark-field illumination; $(B)$ bright-field illumination.

in terms of transcription of these genes (i.e., did not transcribe them), a region of hybridization-free ectoderm would be seen leading the edge of the chordamesoderm; this is not the case.

During midgastrula (stage 12) epiboly of animal region cells leads to an expanded area of ectoderm around much of the embryo. As seen in Figure 5B, cytokeratin mRNAs are expressed over this entire area. The plane of this section does not cut through the neuroectoderm; in a section that does, the absence of hybridization in the preneural region is observed (Fig. 5E). The difference in cytokeratin expression between the neural and epidermal pathways becomes progressively more obvious during the process of neurulation. This is apparent in Figure 6, which shows a cross section through a stage- 14 embryo: The epidermis shows strong hybridization while the neural plate no longer expresses cytokeratin genes. The signal is not present in the neural tissues of any of the subsequent stages.

\section{Localization of cytokeratins in Xenopus embryos}

To investigate the distribution of translation products of cytokeratin mRNAs we prepared antibodies against a conserved carboxy-terminal peptide of type I cytokeratins. These antibodies recognize most, if not all, type I embryonic cytokeratins and visualize their overall distribution (see Materials and methods). No localized immunoreaction was detected in blastulae before the beginning of transcription of embryonic cytokeratin genes; therefore, no cross-reacting maternal cytokeratins are 


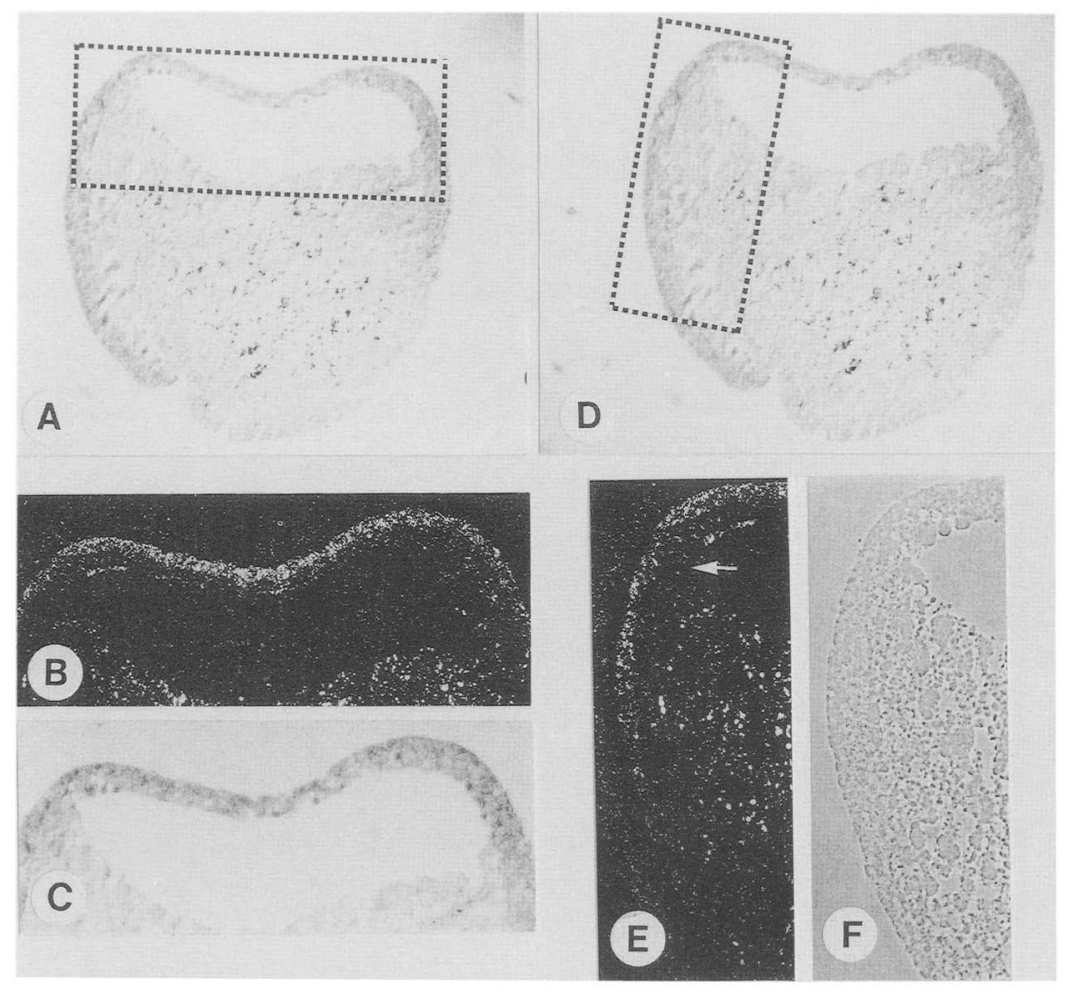

Figure 4. In situ hybridization of DG76 to sections of stage-10 1/2 embryos. Boxed areas in $A$ and $D$ indicate the regions enlarged in $B$, $C$ and $E, F$, respectively. Dark-field $(B)$ and phase-contrast $(C)$ show hybridization of DG76 to the animal region of a stage-10 $1 / 2$ embryo. The entire epithelial ectoderm shows hybridization. Dark-field $(E)$ and phase-contrast $(F)$ show the hybridization to the preneural (dorsal) region. Arrow shows where ectoderm is in contact with the leading edge of chordamesoderm. present in the early embryo. Figure 7 shows the immunoperoxidase staining of a frozen section of a stage- 20 embryo, demonstrating the epidermal localization of the cytokeratins.

Immunofluorescence staining of stage- 18 embryos reveals that both layers of the epidermis react with these antibodies, with the outer layer showing much stronger fluorescence (Fig. 8A). This concentration in the outside layer is in agreement with the in situ hybridization results, and suggests that the differences in the abundance of cytokeratins are regulated at the transcriptional level. To investigate the intracellular distribution of keratins further, we dissociated the cells of this layer and stained the individual cells with cytokeratin antibody. As seen in Figure 8C, the cytokeratins are organized in the cell in the form of filaments, forming meshworks of uneven density. The dense meshwork of filaments faces the outside surface of the embryo, and a much reduced density is visible in regions of the cells that have contact with other cells. This polarity is established from the very beginning of filament polymerization (Fig. 8D). Figure $8 \mathrm{E}$ presents a view of cytokeratin networks in the epidermis of a stage-12 gastrula as seen from outside of the embryo. The localization of the filaments is reminiscent of the localization of maternal cytokeratin in the egg cortex (Wylie et al. 1985), suggesting the presence of localized determinants that promote cytokeratin polymerization. It is possible that these determinants remain in the same location during early development, much the same way the pigment does, and play a role in the assembly of the embryo-specific cytokeratin fibers.

\section{Discussion}

We have followed the accumulation of developmentally regulated epidermal cytokeratin mRNA in Xenopus embryos. At the earliest stage at which they can be detected (stage 9) cytokeratin mRNAs are expressed in a celltype-specific manner. This observation indicates that already in the blastula, before the beginning of gastrulation, different cell types operate according to different transcriptional programs. This is the earliest cell-typespecific transcription reported in amphibian development to date. The cytokeratins are expressed intensely in the entire epithelial ectoderm, much less in the sensorial ectoderm (inner layer of ectoderm or epidermis), and cannot be reliably detected in mesoderm and endoderm. These results may be interpreted to suggest that localized maternal components are responsible for the regulation of epidermal cytokeratin genes. Previous experiments have shown that the activation of these genes is autonomous, i.e., does not require any cell-cell contact (Sargent et al. 1986), a result consistent with the idea of prelocalized components. During gastrulation, the pattern of cytokeratin gene expression is changing. Whereas the entire epithelial ectoderm of the early gastrula is expressing these genes, their transcription in future neural cells is terminated by midgastrula, presumably through inductive interaction with cells of the chordamesoderm. It is worth noting that this inductive effect is a negative one. This result is consistent with a pattern of keratin gene expression based on uneven distribution of maternal components subsequently modified by inductive interactions. 
Figure 5. In situ hybridization of $\mathrm{DG}_{7} 76$ to sections of stage- 12 Xenopus embryos. Planes of sections of $B, C$ and $E, F$ are indicated in $A$ and $D$, respectively. Arrows in $A$ and $D$ indicate the direction of chordamesodermal involution. Dark-field $(B)$ and phase-contrast $(C)$ show hybridization of DG76 to the extending epidermis; the plane of this section does not cross the neuroectoderm. $E$ and $F$ show a cross section; note the lack of hybridization in the neuroectoderm. The apparent signal in the chordamesoderm (arrows) is due to trapped air bubbles and not to silver grains.

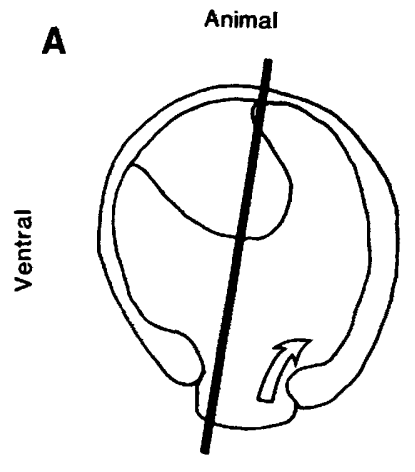

Vegetal
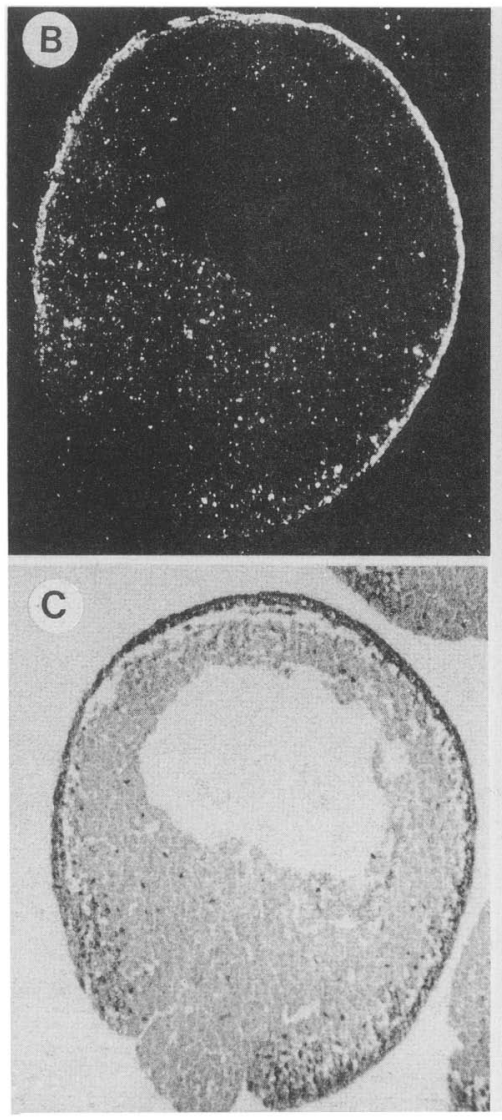

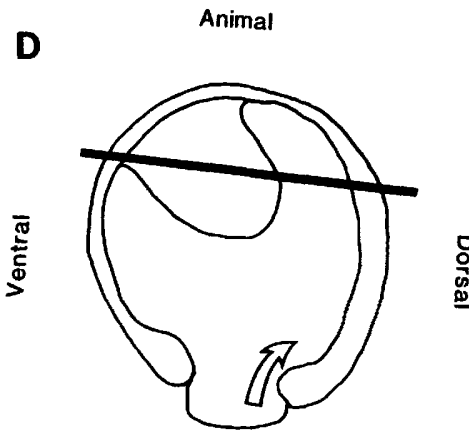

Vegetal

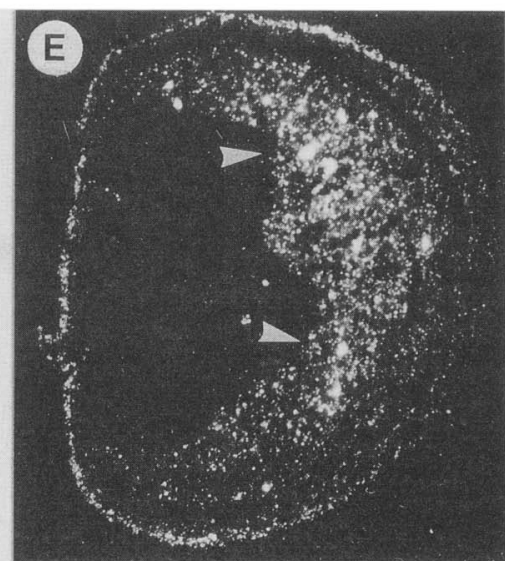

F

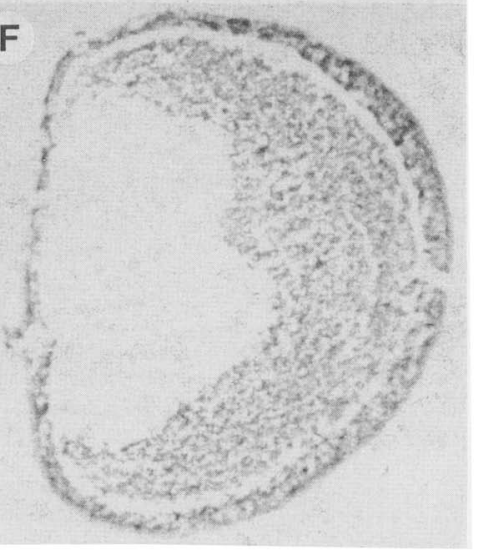

The results reported here are the first demonstration that the preneural and preepidermal ectoderm initially express some identical genes, which are subsequently inactivated in preneural ectoderm. The potential of epidermal and neural cells to express the same genes has been recognized previously (Akers et al. 1986; Jones and Woodland 1986), using markers that can first be detected by late gastrula. The progressive divergence in gene expression between epidermal and neural ectoderm helps explain the decreasing competence of ectodermal cells to be neutralized or mesodermalized (Chuang 1955; Leikola 1963; Grunz 1968). One could argue that the expression of a certain set of cell-type-specific genes reflects a commitment of these cells to the corresponding developmental direction. For example, as cells express certain epidermal genes, it might become increasingly more difficult to change their fate. In the case of cytokeratins, this fixation could be due in part to the assembly of intermediate filament structures in the cells.

The mechanism of neural induction is unknown, although a number of substances have been identified that mimic the action of in vivo induction /Tiedemann and Tiedemann 1956; Yamada 1958; Faulhaber 1970, Kawakami et al. 1977|. Our experiments do not provide further insight into this process except to emphasize the observation that induction is not restricted to the cell layer in contact with chordamesoderm. This follows from the fact that the layer of cells that is expressing the 

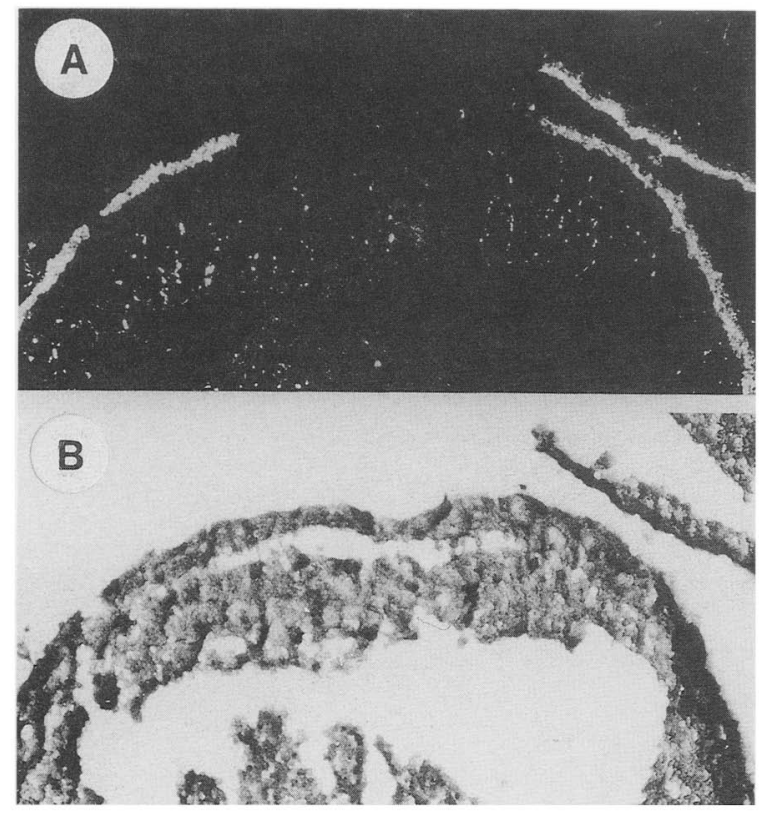

Figure 6. In situ hybridization of DG76 to a section of stage-14 neurula. Neural plate is at top. The absence of cytokeratin RNA in the neural plate region is obvious. (A) Dark-field microscopy; (B) phase-contrast.

bulk of cytokeratin mRNA, i.e., the outer or epithelial ectoderm, does not come into direct contact with the inducing tissue. The major inductive effect on cytokeratin expression must, therefore, "pass through" the inner ectodermal layer.

During accumulation of cytokeratins and their mRNAs, the protein distribution tends to reflect the distribution of mRNA. Intermediate filaments form and are assembled into intricate meshworks. The polymerization of these filaments starts in the epithelial layer of the epidermis at stage $91 / 2$, only slightly later $(1-2 \mathrm{hr})$ than the first appearance of cytokeratin transcripts, indi- cating that there is no appreciable delay between transcription and translation of cytokeratins. Polymerization of filaments starts in the region of the cell that is facing the outside of the embryo, and this polarity is maintained through development. The filaments in the sensorial layer of the epidermis never reach the density of the outside layer and they are distributed uniformly throughout the cell.

This is the first time that in situ hybridization has been successfully used for the analysis of gene expression in early amphibian embryos. In situ hybridization to later stages of Xenopus embryos was performed using frozen sections (Dworkin-Rastl et al. 1986), but due to fragility of sections from early stages, this technology has a limited value for analysis of such material. In situ hybridization to paraffin and methacrylate sections (Jamrich et al. 1984), together with feasibility of analysis of transcription in Xenopus oocytes by in situ hybridization to nascent transcripts on lampbrush chromosomes (Jamrich et al. 1983), provides cytogenetic means to study gene expression in this amphibian from oogenesis through all of embryonic development.

\section{Materials and methods}

\section{Animals}

Adult Xenopus laevis were purchased from Nasco (Wisconsin). Albino animals were obtained from Dr. R. Tompkins (New Orleans). Embryos and tadpoles were reared from in vitro-fertilized eggs. Developmental stages were classified according to Nieuwkoop and Faber (1967).

\section{Antibody production}

A 14-residue synthetic polypeptide corresponding to the common carboxyl terminus of the proteins encoded by DG81 and DG70 (Winkles et al. 1985) was used to immunize rabbits by the method described by Benoit et al. (1982). The antiserum was shown to react specifically with several type I keratins found in Xenopus embryos, including species identified as corresponding to DG70 and DG81 (J.A. Winkles et al., unpubl.).

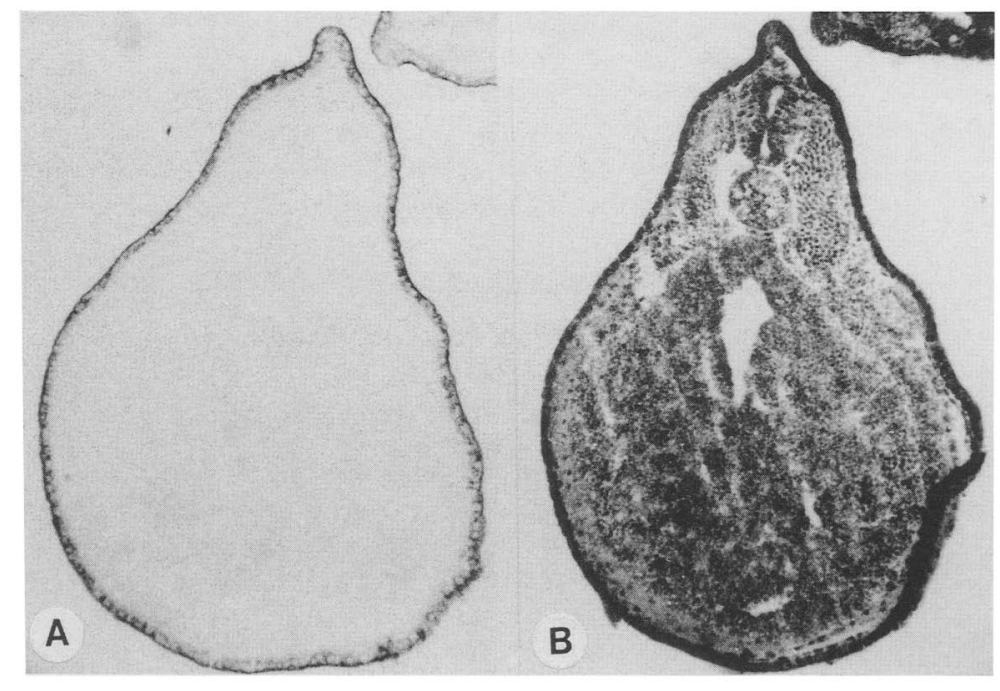

Figure 7. Immunoperoxidase staining of a frozen section of a stage- 25 embryo using cytokeratin antibodies. Staining is limited to the epidermis of the embryo. (A) Immunoperoxidase staining; $(B)$ phasecontrast. 
Figure 8. Indirect immunofluorescence of frozen section and dissociated cells with cytokeratin antibodies. Two epidermal cell layers are decorated by these antibodies. The epithelial layer shows a concentration of antibodies in the region facing the outside of the embryo. (A) Immunofluorescence. $(B)$ Phasecontrast. (C) Indirect immunofluorescence of a single dissociated epidermal cell from stage-18 epithelial ectoderm; the epidermal cytokeratins are assembled into a network of filaments with well-defined intracellular polarity. $(D)$ Indirect immunofluorescence of a dissociated cell from stage-11 embryo; the polarity of the filament network is already apparent. $|E\rangle$ Indirect immunofluorescence of partially dissociated epidermis of stage-12 embryos as viewed from outside the embryo.
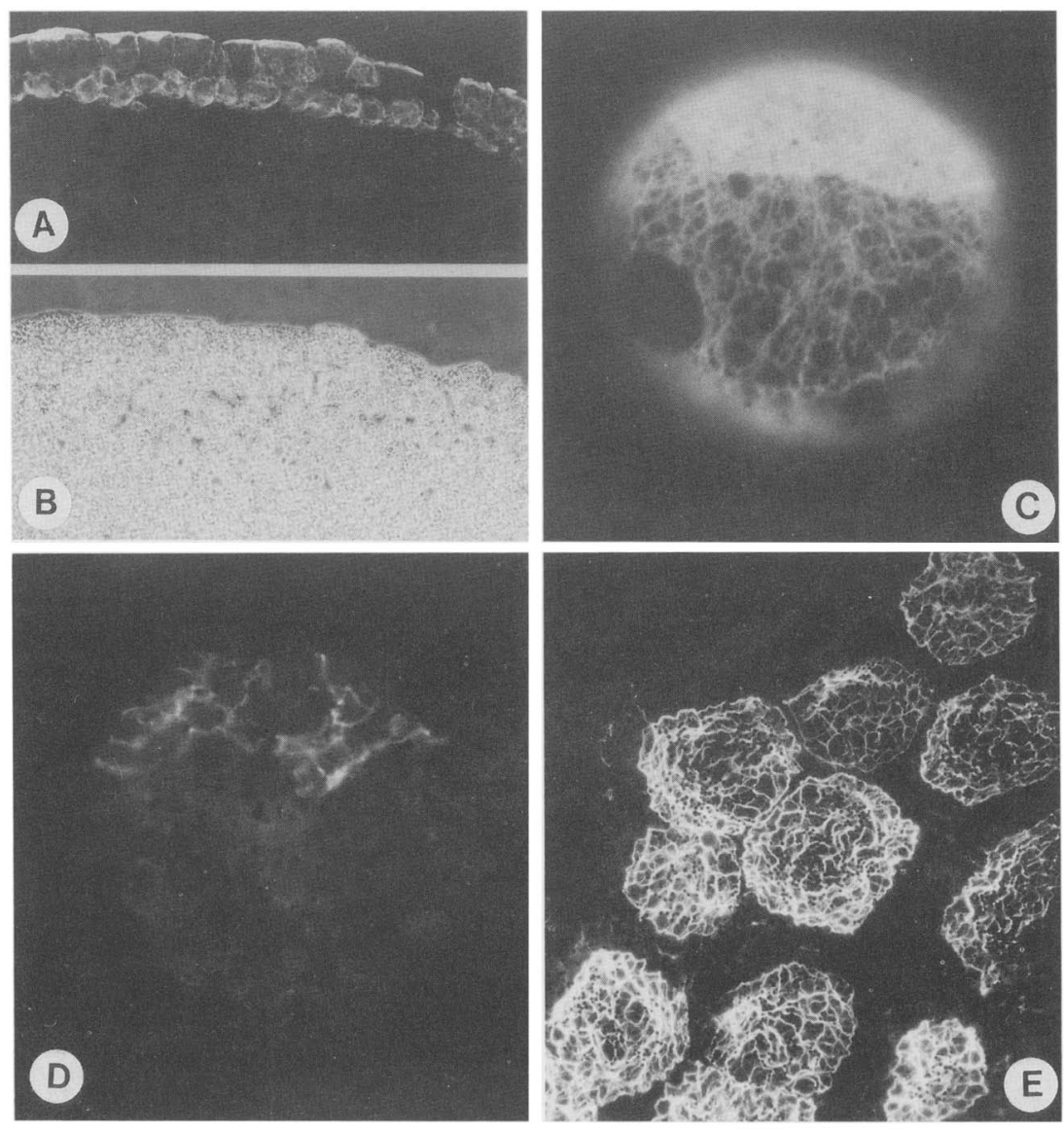

\section{Cell dissociation}

Microdissected ectoderm was placed in Barth media without $\mathrm{Ca}^{++}$and $\mathrm{Mg}^{++} \mid$Gurdon 1977$)$ and containing $5 \%$ of Newport and Kirschner dissociation buffer (Newport and Kirschner 1982). Under these conditions, the epithelial layer of cells will separate from the sensorial cells. The epithelial layer can be picked up as a sheet of cells; the sensorial layer dissociates rather quickly into single cells. We transferred the cells in a drop of media onto a polylysine-coated slide and added a drop or two of $95 \%$ ethanol. This generally causes further disruption of the ectodermal layer and the attachment of some cells to the slide. At this point, the slide is immersed in ice-cold 95\% ethanol for $10 \mathrm{~min}$. Slides were washed in phosphate-buffered saline (PBS) for 10-20 min prior to immunocytochemistry.

\section{In situ hybridization}

Methacrylate embedding is as described in Jamrich et al. (1984) and was used in Figure 1. All other experiments used paraffin embedding as modified from various published procedures (Angerer and Angerer 1981; Akam 1982; Ingham 1985). Albino embryos were used in most experiments, including all figures shown in this paper. Embryos were dejellied in $2 \%$ cysteine $/ \mathrm{pH}$ 7.8) and fixed in 4\% paraformaldehyde in PBS for 15-60 min. Embryos were dehydrated through an alcohol series, cleared in xylene, and embedded in paraffin. Five-micrometer sections were cut on an ultramicrotome, and placed on a drop of water on a polylysine-coated slide. When dried, the slides were placed in xylene for $15 \mathrm{~min}$ to remove paraffin and rehydrated in an alcohol series prior to hybridization. The probes used were single-stranded ${ }^{3} \mathrm{H}$-labeled cRNAs prepared from M13 clones (Diaz et al. 1981 !.

Indirect immunofluorescence

Sections and dissociated cells were reacted with anti-cytokeratin antibodics diluted in PBS containing $16 \%$ fetal calf serum, $1 \%$ bovine scrum albumin (BSA), $0.05 \%$ Tween 20 for $30 \mathrm{~min}$ washed for $30 \mathrm{~min}$ in PBS, reacted with secondary antibodies for $30 \mathrm{~min}$, and washed again with PBS.

\section{Frozen sections}

Embryos were frozen in OCT embedding medium by placing the specimen on the metal specimen holder on dry ice. Eightmicrometer sections were cut on a cryostat. Sections were dried and used without further fixation.

\section{RNA extraction and analysis}

RNA purification and gel blot hybridization techniques were carried out as described previously (Sargent et al. 1986). In each experiment, RNA from equal numbers of cells (usually 1000) was compared. Cell number was determined by hybridization of alkali-hydrolized nucleic acid to a subclone of the 1723 element, a highly repeated sequence present in the genome (Kay and Dawid 1983). If the RNA : DNA ratio of two samples differed by more than a factor of 2, RNA from unfertilized eggs, which does not hybridize with the keratin probes (Sargent and Dawid 1983), was added to equalize the amount of material loaded onto the nylon filter. 


\section{Acknowledgments}

We wish to thank Erzsebet Jonas and Jeff Winkles for providing us with materials for these experiments, Robert Tompkins for albino frogs, and Kathi Mahon for a critical reading of this manuscript.

\section{References}

Akam, M. 1982. The location of Ultrabithorax transcripts in Drosophila tissue sections. EMBO I. 2: 2075-2083.

Akers, M.R., C.R. Phillips, and N.K. Wessels. 1986. Expression of an epidermal antigen used to study tissue induction in the early Xenopus laevis embryo. Science 231: 613-616.

Anderson, D.M., J.D. Richter, M.E. Chamberlin, D.H. Price, R.J. Britten, L.D. Smith, and E.H. Davidson. 1982. Sequence organization of poly(A) RNA synthesized and accumulated in lampbrush stage Xenopus laevis oocytes. I. Mol. Biol. 155: $281-304$.

Angerer, L.M. and R.C. Angerer. 1981. Detection of poly A+ RNA in sea urchin eggs and embryos by quantitative in situ hybridization. Nucleic Acids Res. 9: 2819-2840.

Bachvarova, R. and E.H. Davidson. 1966. Nuclear activation at the onset of amphibian gastrulation. J. Exp. Zool. 163: 285295.

Ballantine, J.E.M., H.R. Woodland, and E.A. Sturgess. 1979. Changes in protein synthesis during the development of Xenopus laevis. J. Embryol. Exp. Morphol. 51: 137-153.

Benoit, R., P. Bohlen, N. Ling, A. Briskin, F. Esch, P. Brazeau, S.Y. Ying, and R. Guillemin. 1982. Presence of somatostatin-28-(1-12) in hypothalamus and pancreas. Proc. Natl. Acad. Sci. 79: 917-921.

Bravo, R. and J. Knowland. 1979. Classes of protein synthesized in oocytes, eggs, embryos and different tissues of Xenopus laevis. Differentiation 13: 101-108.

Chuang, H.H. 1955. Untersuchungen uber die Reaktionsfahigkeit des Ektoderms mittels sublethaler Cytolyse. I. Acad. Sinica 4: 151-186.

Davidson, E.H. 1986. Gene activity in early development, 3rd ed., p. 670. Academic Press, Orlando.

Dawid, I.B. and T.D. Sargent. 1986. Molecular embryology in amphibians: New approaches to old questions. Trends Genet. 2: 47-50.

Diaz, M.O., G. Barsacchi-Pilone, K.A. Mahon, and J.G. Gall. 1981. Transcripts from both strands of a satellite DNA occur on lampbrush chromosome loops of the newt Notophthalmus. Cell 24: 649-659.

Dworkin-Rastl, E., D.B. Kelley, and M.B. Dworkin. 1986. Localization of specific mRNA sequences in Xenopus laevis embryos by in situ hybridization. J. Embryol. Exp. Morphol. 91: $153-168$.

Faulhaber, I. 1970. Anreicherung des vegetalisierenden Induktionsfaktor aus der Gastrula des Krallenfrosches (Xenopus laevis) und Abgrenzung des Molekulargewichsbereiches durch Gradientenzentrifugation. Z. Physiol. Chem. 351: $588-594$.

Franz, J.K. and W.W. Franke. 1986. Cloning of cDNA and amino acid sequence of a cytokeratin expressed in oocytes of Xenopus laevis. Proc. Natl. Acad. Sci. 83: 6475.

Gerhart, J.C. 1980. Mechanisms regulating pattern formation in the amphibian egg and early embryo. In Biological regulation and development (ed. R.F. Goldberger), vol. 2, p. 133-316. Plenum, New York.

Godsave, S.F., C.C. Wylie, E.B. Lane, and B.H. Anderton. 1984. Intermediate filaments in the Xenopus oocytes: The appearance and distribution of cytokeratin-containing filaments. $J$. Embryol. Exp. Morphol. 83: 157.
Grunz, H. 1968. Experimentelle Untersuchungen uber die Kompetenzverhaltnisse fruher Entwicklungsstadien des Amphibien-Ectoderms. Wilhelm Roux' Arch. 160: 344-374.

Gurdon, J.B. 1977. Methods for nuclear transplantation in Amphibia. Methods Cell Biol. 16: 125-139.

Gurdon, J.B., T.J. Mohun, S. Fairman, and S. Brennan. 1985. All components required for the eventual activation of musclespecific actin genes are localized in the subequatorial region of an uncleaved amphibian egg. Proc. Natl. Acad. Sci. 82: $139-143$.

Hafen, E., M. Levine, R. Garber, and W.J. Gehring. 1983. An improved in situ hybridization method for the detection of cellular RNAs in Drosophila tissue sections and its application for localizing transcripts of the homeotic Antennapedia gene complex. EMBO I. 2: 617-623.

Holtfreter, J. and V. Hamburger. 1955. Embryogenesis: Progressive differentiation-Amphibians. In Analysis of development (ed. B.H. Willier, P.A. Weiss, and V. Hamburger), p. 230-296. W.B. Saunders, Philadelphia.

Ingham, P.W., K.R. Howard, and D. Ish-Horowitz. 1985. Transcription pattern of the Drosophila segmentation gene hairy. Nature 318: 439-445.

Jacobson, M. and U. Rutishauser. 1986. Induction of neural cell adhesion molecule (NCAM) in Xenopus embryos. Dev. Biol. 116: 524 .

Jamrich, M., R. Warrior, R. Steele, and J.G. Gall. 1983. Transcription of repetitive sequences on Xenopus lampbrush chromosomes. Proc. Natl. Acad. Sci. 80: 3364-3367.

Jamrich, M., K.A. Mahon, E.R. Gavis, and J.G. Gall. 1984. Histone RNA in amphibian oocytes visualized by in situ hybridization to methacrylate-embedded tissue sections. EMBO I. 3: 1939-1943.

Jamrich, M., T.D. Sargent, and I.B. Dawid. 1985. Altered morphogenesis and its effects on gene activity in Xenopus laevis embryos. Cold Spring Harbor Symp. Quant. Biol. 50: $31-$ 35.

Jonas, E., T.D. Sargent, and I.B. Dawid. 1985. Epidermal keratin gene expressed in embryonic Xenopus laevis. Proc. Natl. Acad. Sci. 82: 5413-5417.

Jones, E.A. 1985. Epidermal development in Xenopus laevis: The definition of a monoclonal antibody to an epidermal marker. J. Embryol. Exp. Morphol. 89(suppl.): 155-166.

Jones, E.A. and H.R. Woodland. 1986. Development of the ectoderm in Xenopus: Tissue specification and the role of cell association and division. Cell 44: 345-355.

Kawakami, I., S. Noda, K. Kurihara, and K. Okuma. 1977. Vegetalising factor extracted from the fish swimbladder and tested on presumptive ectoderm of Triturus embryos. Wilhelm Roux' Arch. 182: 1-7.

Kay, B.K. and I.B. Dawid. 1983. The 1723 element: A long, homogeneous, highly repeated DNA unit interspersed in the genome of Xenopus laevis. I. Mol. Biol. 170: 583-596.

Keller, R.E. 1975. Vital dye mapping of the gastrula and neurula of Xenopus laevis. I. Prospective areas and morphogenetic movements of the superficial layer. Dev. Biol. 42: 222-241.

- 1976. Vital dye mapping of the gastrula and neurula of Xenopus laevis. I. Prospective areas and morphogenetic movements in the deep region. Dev. Biol. 51: 118 .

Leikola, A. 1963. The mesodermal and neural competence of isolated gastrula ectoderm studied by heterogeneous inductors. Ann. Zool. Soc. "Vanamo" 25: 1-50.

Nakamura, O., H. Takasaki, and T. Mizohata. 1970. Differentiation during cleavage in Xenopus laevis. I. Acquisition of self-differentiation capacity of the dorsal marginal zone. Proc. Jap. Acad. 46: 694-699.

Nakamura, O., H. Takasaki, T. Okumoto, and H. Iida. 1971. Differentiation during cleavage in Xenopus laevis. II. Devel- 
Jamrich et al.

opment of inductive activity of the organizer. Proc. Jap. Acad. 47: 203-208.

Newport, J. and M. Kirschner. 1982. A major developmental transition in early Xenopus embryos. I. Characterization and timing of cellular changes at the midblastula stage. Cell 30: 675-686.

Nieuwkoop, P.D. 1969. The formation of mesoderm in urodelean amphibians. I. Induction by the endoderm. Wilhelm Roux' Arch. 162: 341-373.

. 1973. The "organisation center" of the amphibian embryo: Its origin, spatial organisation and morphogenetic action. Adv. Morphol. 10: 1.

Nieuwkoop, P.D. and J. Faber. 1967. Normal table of Xenopus laevis (Daudin), 2nd ed. North-Holland Publishing Co., Amsterdam.

Sargent, T.D. and I.B. Dawid. 1983. Differential gene expression in the gastrula of Xenopus laevis. Science 222: 135-139.

Sargent, T.D., M. Jamrich, and I.B. Dawid. 1986. Cell interactions and the control of gene activity during early development of Xenopus laevis. Dev. Biol. 114: 238-246.

Scharf, S.R. and J.C. Gerhart. 1983. Axis determination in eggs of Xenopus laevis: A critical period before first cleavage, identified by the common effects of cold, pressure, and ultraviolet radiation. Dev. Biol. 99: 75-87.

Slack, J.M.W. 1984. Regional biosynthetic markers in the early amphibian embryo. J. Embryol. Exp. Morphol. 80: 289-319.

- 1985. Peanut lectin receptors in the early amphibian embryo: Regional markers for the study of embryonic induction. Cell 41: 237-247.

Smith, L.D. and J.D. Richter. 1985. Synthesis, accumulation, and utilization of maternal macromolecules during oogenesis and oocyte maturation. In Biology of Fertilization (ed. A. Monroy and C. Metz), pp. 141-188. Academic Press, New York.

Tiedemann, H. and H. Tiedemann. 1956. Versuche zur chemischen Kennzeichnung von embryonalen Induktionsstoffen. Hoppe-Seyler's Z. Physiol. Chem. 306: 7-32.

Vincent, J.P., G.F. Oster, and J.C. Gerhart. 1986. Kinematics of gray crescent formation in Xenopus eggs: The displacement of subcortical cytoplasm relative to the egg surface. Dev. Biol. 113: 484-500.

Vogt, W. 1929. Gestaltungsanalyse am Amphibienkeim mit ortlicher Vitalfarbung. Wilhelm Roux' Arch. 120: 384-706.

Winkles, J., T.D. Sargent, D.A.D. Parry, E. Jonas, and I.B. Dawid. 1985. Developmentally regulated cytokeratin gene in Xenopus laevis. Mol. Cell. Biol. 5: 2575-2581.

Wylie, C.C., D. Brown, S.F. Godsave, J. Quarmby, and J. Heasman. 1985. The cytoskeleton of Xenopus oocytes and its role in development. $/$. Embryol. Exp. Morphol. 89(suppl.): $1-15$.

Yamada, T. 1958. Induction of specific differentiation by samples of proteins and nucleoproteins in the isolated ectoderm of Triturus gastrulae. Experientia 14: 81 -87. 


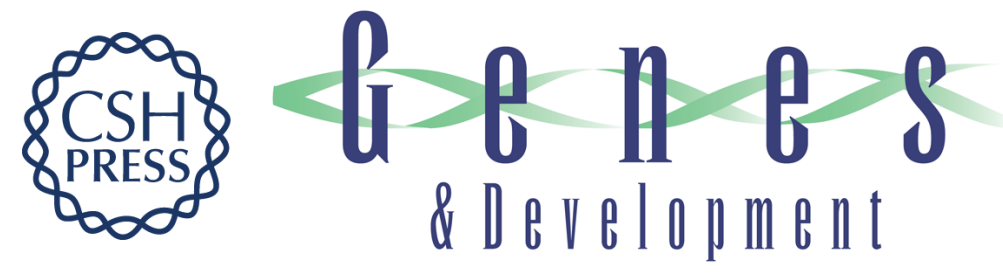

\section{Cell-type-specific expression of epidermal cytokeratin genes during gastrulation of Xenopus laevis.}

M Jamrich, T D Sargent and I B Dawid

Genes Dev. 1987, 1:

Access the most recent version at doi:10.1101/gad.1.2.124

References This article cites 48 articles, 9 of which can be accessed free at: http://genesdev.cshlp.org/content/1/2/124.full.html\#ref-list-1

License

Email Alerting

Receive free email alerts when new articles cite this article - sign up in the box at the top Service right corner of the article or click here.

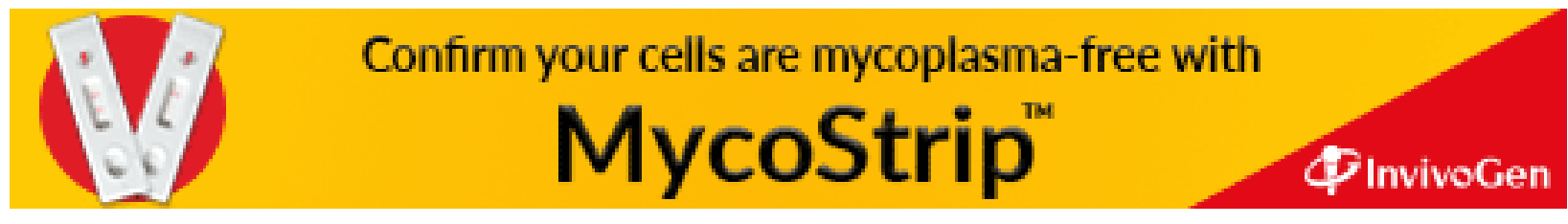

